\title{
The Role of Self-Regulation in Supporting Korea's Securities Markets
}

\author{
Bernard S. Black*
}

\begin{abstract}
This short article was initially prepared for a December 2001 conference sponsored by the Korea Stock Exchange (KSE). It reviews the scope of self-regulation by stock exchanges and offers suggestions for the main Korean stock exchanges, the KSE and the KOSDAQ. I argue that self-regulation should be understood broadly to include regulation of listed companies through quality standards, disclosure standards, and governance rules; regulation of broker-dealers; regulation of trading; and, perhaps most basic, regulation of the exchange's organizational structure. The most important elements of selfregulation are regulation of listed companies and the exchange's organizational structure (which impacts its incentives to engage in other forms of self-regulation). To compete for trading in shares of cross-listed Korean companies, Korea will need both legislative change and stronger self-regulation of listed companies. The government should amend the Securities Transaction Law to repeal the securities transaction tax and permit demutualization of the KSE and the KOSDAQ. The government and the stock exchanges must upgrade both the on-the-ground reality (which will lag behind changes in formal rules) and investor perception (which will lag behind the on-the-ground reality) of Korea's disclosure and corporate governance regime. Stronger listing standards can be important components of that investor protection effort.
\end{abstract}

* Professor of Law, Stanford Law School, Stanford, California, USA. Tel. +1-650-725-9845, email bblack@stanford.edu. An earlier version of this article was published in Hwa-Jin Kim, ed., SELF-REGULATION IN THE KOREAN SECURITIES MARKET 17-30 (2003). I thank participants in the Korea Stock Exchange conference on Self-Regulatory Institutions in the Korean Stock Market and also Hwa Jin Kim and Kon Sik Kim for their comments on earlier drafts. 



\section{Introduction: The Multifaceted Nature of Self-Regulation}

To discuss self-regulation by stock exchanges, we need to define what this term means. I will define self-regulation in securities markets broadly, to include any actions by the professional participants in securities markets, acting through professional organizations or through the stock exchange, in three broad areas (see Table I):

(1) regulation of the quality and behavior of public companies, through listing standards that combine minimum size and solvency standards, disclosure standards, and corporate governance standards;

(2) regulation of broker-dealers, both in their dealings with each other and in their dealings with customers; and

(3) regulation of trading, including trade disclosure and investigation and regulation of insider trading, market manipulation, excessive commissions, and front running.

The list in Table I of the different tasks included within self-regulation highlights the extent to which self-regulation is not a one concept, but instead covers a number of very different areas. An exchange can do wonderfully at self-regulation in one area and quite badly in another area. The incentives of the exchange and of the broker-dealers who are exchange members to cause the exchange to regulate effectively differ greatly across these different areas.

Even this list is incomplete, because it omits the role of the securities regulator -- in Korea, the Financial Supervisory Commission -- in overseeing the quality of selfregulation and pressing for improvements, especially in areas where the broker-dealers or the exchange may have incentives not to regulate too strictly.

It would require a far longer article than this one to discuss the nature of selfregulation, what the Korea Stock Exchange has done to date, what self-regulation can reasonably accomplish, and how the Korea Stock Exchange might do better, across each of these areas. I will therefore gloss over much of this complexity, stay mostly at a higher level of generality, and offer only a number of broad comments, principally about what Korea's stock exchanges can -- and likely must, on pain of losing trading to other exchanges -- do to improve their regulation of listed companies. ${ }^{12}$

1) For overviews of the strengths and drawbacks of self-regulation in financial markets see BRIAN R. CHEFFINS, Company LaW: Theory, Structure, and OPERAtion (1997); Paul G. Mahoney, The Exchange as Regulator, 83 VIRGINIA LAW REVIEW 1453-1500 (1997). 


\section{[ Table 1 ] Areas of Self Regulation}

\begin{tabular}{|c|c|}
\hline Area of Self Regulation & Example Rules or Areas Covered \\
\hline \multicolumn{2}{|l|}{ Regulation of Listed Companies } \\
\hline size and solvency standards & $\begin{array}{l}\text { minimum share price } \\
\text { minimum market capitalization } \\
\text { minimum public float } \\
\text { minimum net assets } \\
\text { minimum earnings }\end{array}$ \\
\hline disclosure standards & $\begin{array}{l}\text { audited financial reports } \\
\text { periodic reporting } \\
\text { disclosure of important events } \\
\text { disclosure of self-dealing transactions } \\
\text { disclosure of ownership and trading by insiders } \\
\text { disclosure of executive compensation }\end{array}$ \\
\hline corporate governance standards & $\begin{array}{l}\text { one share, one vote } \\
\text { minimum number of independent directors } \\
\text { audit committee } \\
\text { shareholder approval of important transactions } \\
\text { large share issuances } \\
\text { stock option plans } \\
\text { executive compensation } \\
\text { self-dealing transactions }\end{array}$ \\
\hline \multicolumn{2}{|l|}{ Regulation of Broker-Dealers } \\
\hline broker-exchange relations & clearance and settlement rules \\
\hline broker-broker relations & rules for settling disputes \\
\hline broker-customer relations & $\begin{array}{l}\text { rules of fair dealing } \\
\text { discipline of brokers who mistreat customers } \\
\text { arbitration of disputes } \\
\text { disclosure of commissions } \\
\text { maximum commissions (markup/markdown) }\end{array}$ \\
\hline \multicolumn{2}{|l|}{ Regulation of Trading } \\
\hline transparency rules & $\begin{array}{l}\text { prompt reporting of trade price and volume } \\
\text { consolidated reporting, including off-exchange trades }\end{array}$ \\
\hline insider trading & market surveillance for suspicious trades \\
\hline investor access rules & $\begin{array}{l}\text { price/time priority rules } \\
\text { order splitting rules }\end{array}$ \\
\hline
\end{tabular}




\section{Modes of Self-Regulation}

To begin with, in each substantive area of self-regulation, there are a number of regulatory structures within which self-regulation can operate, that give different weight to self-regulation compared to government regulation. Some alternative approaches are shown in Table II. They range from what we can call primary selfregulation, in which the exchange is the principal regulator, to minimal self-regulation, in which the exchange is largely passive, and the legislature and a regulatory agency do essentially all of the important regulating. Various intermediate possibilities exist as well. Examples of each of these can be found in various stock exchanges around the world, either today or in the past.

As a broad generalization, markets that have begun in a mode of primary selfregulation, including the United States and the United Kingdom, have migrated toward greater regulatory intervention, in response to the shortcomings of self-regulation, both real and perceived. The lesson of experience is that primary self-regulation is not optimal. In particular, exchanges often defer too strongly to major listed firms and major broker-dealers.

At the same time, self-regulation has important advantages that government regulation lacks, notably flexibility and adaptation to changing external circumstances. It is likely no accident that strong securities markets, including the United States and the United Kingdom, retain a healthy dose of self-regulation. Thus, the lesson of experience is also that minimal self-regulation is not optimal either.

Quite likely, a better approach is somewhere in the middle, involving some form of what we can loosely call parallel regulation. In a system of parallel regulation, the exchange and a regulatory agency share regulatory authority over listed companies, broker-dealers, and trading. The regulatory agency also oversees the exchange's selfregulatory efforts, and can prod the exchange to act more vigorously. ${ }^{2)}$

2) Compare Adam C. Pritchard, Self-Regulation and Trust in the Securities Markets, in Hwa-Jin Kim, ed., SELFRegulation in the Korean SeCurities Market 31-53 (2003), Adam C. Pritchard, Self-Regulation and Securities Markets, REgUlation, Spring 2003, at 32-39; and Mahoney (1997), supra note 1. These authors advocate something closer to what I call, in Table 2, primary self-regulation with oversight. 


\section{[ Table 2 ] Modes of Self-Regulation}

\begin{tabular}{l|l}
\hline Mode of Self-Regulation & Explanation and Discussion \\
\hline primary self regulation & $\begin{array}{l}\text { The stock exchange has exclusive or near-exclusive authority, } \\
\text { with no or minimal oversight by a regulatory agency. }\end{array}$ \\
\hline $\begin{array}{l}\text { primary self-regulation with } \\
\text { oversight }\end{array}$ & $\begin{array}{l}\text { The stock exchange has exclusive or near-exclusive authority, } \\
\text { but is subject to oversight of the effectiveness of self regulation } \\
\text { by a regulatory agency. }\end{array}$ \\
\hline $\begin{array}{l}\text { parallel regulation } \\
\text { exchange investigates cases, } \\
\text { regulator decides on penalty (or } \\
\text { reviews penalty set by exchange) }\end{array}$ & $\begin{array}{l}\text { The stock exchange and a regulatory agency have overlapping } \\
\text { authority. Generally, the exchange is also subject to oversight of } \\
\text { the effectiveness of self-regulation by the regulatory agency. } \\
\text { exchange can impose on broker-dealers (expulsion, fines, limits } \\
\text { increase, decrease, or reverse the exchange-imposed penalty. }\end{array}$ \\
\hline & $\begin{array}{l}\text { Almost all regulation is done, in practice, either by legislation or } \\
\text { a regulatory agency, or by the exchange at the regulator's } \\
\text { initiative, whether or not the exchange retains formal self- } \\
\text { regulatory power. }\end{array}$ \\
\hline
\end{tabular}

\section{The Overall Role of Self-Regulation in Securities Markets}

In my judgment, self-regulation by stock exchanges can be a significant component of the overall web of legal and market institutions that underlies a strong stock market. The most important role that self-regulation can play, I believe, is through listing standards that regulate the quality of listed companies, the disclosure provided by these companies, and the corporate governance practices that listed companies follow. In the other two broad areas covered by self-regulation -- regulation of broker-dealers, and regulation of trading, I believe that self-regulation can be valuable, but it is not a primary factor in determining the success of a country's securities markets. Other factors are more important.

In my article on The Legal and Institutional Preconditions for Strong Securities Markets, I argue that there are two necessary but not sufficient conditions for a country to have strong securities markets. A country's laws and related market institutions must give minority shareholders: (i) good information about the value of a company's 
business; and (ii) confidence that they will not be cheated out of that value by a company's insiders (its managers and controlling shareholders). ${ }^{3)}$ I then list 25 core legal and market institutions that I believe to be the most important for producing good disclosure and controlling self-dealing. Self-regulation by stock exchanges is not one of these 25 core institutions. It appears instead in a supplemental list of about a dozen additional useful institutions. This placement reflects my sense of the importance of self-regulation, relative to other market-supporting institutions.

Here is what I say, with regard to stock exchange regulation of broker-dealers, in their capacity as investment bankers:

Self-regulatory organizations. Self-regulation, through a voluntary or mandatory self-regulatory organization that is itself subject to regulatory oversight, is a useful supplement to government regulation of [investment banks and other] reputational intermediaries. Just as liability to investors makes reputational intermediaries more willing to insist on good disclosure, it makes the intermediaries more willing to create a strong self-regulatory organization and to support the self-regulatory organization's efforts to discipline errant members.

The central problem, for self-regulation of broker-dealers, is that an exchange cannot easily regulate its broker-dealers more strongly than the broker-dealers want. If the exchange is controlled by broker-dealer members this is almost a tautology. If the members don't face external pressure to behave well, they won't want strong exchange regulation that constrains how they behave toward their customers. What they don't want, they won't get. Even with a regulatory agency supervising the exchange's selfregulation, and prodding the exchange to do more, there is only so much that an organization run by broker-dealers will do to discipline errant members.

This is why, in the excerpt above, I stress the interplay between self-regulation and liability to investors. Some outside force is needed, I believe, to prod the exchange into putting teeth into self-regulation. Concern for building a strong market is too often insufficient. That outside force can come from regulatory oversight, the broker-dealers'

3) Bernard Black, The Legal and Institutional Preconditions for Strong Securities Markets, 48 UCLA LAW REVIEW 781-858 (2001), available at <http://ssrn.com/abstract=182169> (Social Science Research Network). 
fear of liability to investors, or both.

The weakness of stock exchange self-regulation, especially if external pressure is weak, should not be surprising. To my knowledge, no professional organization, in any profession, in any country, does a strong job in disciplining errant members. Associations of lawyers are lax in disciplining bad lawyers. Associations of physicians are lax in disciplining bad physicians. Associations of accountants are lax in disciplining bad accountants, as the United States famously became aware after the Enron, WorldCom, Tyco and other recent scandals, which led to the creation of a Public Company Accounting Oversight Board -- a new regulatory agency, itself supervised by our Securities and Exchange Commission that perhaps will do to accountants what the accountants would not do to themselves. And stock exchanges that are run by broker-dealer members are lax in disciplining bad broker-dealers.

A professional association or a stock exchange can do a reasonable job of disciplining members for malfeasance -- say when a lawyer or a broker-dealer steals money from a client, or a doctor is habitually drunk. All other members benefit from expelling members who misbehave in so extreme a fashion. But even this requires first that membership in the self-regulatory organization be mandatory -- which it is not, at present, for broker-dealers in Korea.

At the same time, for garden variety negligence, or overcharging a client, or analysts at investment banks touting a company so their employer can underwrite the company's securities, professional associations and stock exchanges do a bad job of policing this conduct. In many cases, professional associations and stock exchanges don't even pretend to police this moderately anti-consumer conduct very thoroughly. In some cases, they try to maintain supra-competitive prices for their members' services -- through minimum fee schedules for lawyers or minimum commissions for stock trading, which the New York Stock Exchange maintained until told to stop by our legislature.

In the end, there are practical limits on how strictly a stock exchange can police its members. The pressures for lax enforcement are too strong. The gains to brokerdealers from policing themselves aggressively are small, if they are positive at all. Broker-dealers as a whole may benefit from a system that permits low-level overcharging. The broker-dealers profit and the customers lose. Moreover, even if a broker-dealer may not profit in the long run, net of reputational costs, its employees may prefer weaker sanctions in the (highly visible) short run. 
To be sure, a good scandal or two can help. An exchange that faces an urgent need to restore public confidence may be able to obtain member consensus on actions that it would never consider in quieter times. Thus, for example, the NYSE and the NASD recently responded to scandals involving analysts touting firms to obtain underwriting business by adopting rules to better control analyst conflict of interests. Still, quieter times will return, and lax enforcement will likely return with them.

In contrast, stock exchanges can do a fine job of policing how brokers act toward each other. All sides want quick, efficient settlement of trades and disputes about trades. Thus, we must recognize the areas where self-regulation is likely to be more and less effective. When the regulatory problem to be addressed is broker-dealers who moderately overcharge or otherwise take advantage of their clients, but stop short of outright theft, self-regulation must be supplemented by government oversight of the exchange's efforts, by direct liability of broker-dealers to investors, and probably by direct government regulation.

\section{The Importance of Strong Listing Standards}

Stock exchanges can play an important self-regulatory role in policing listed companies. In the United States and the United Kingdom, many important rules governing listed companies were pioneered by the New York Stock Exchange and the London Stock Exchange. Sometimes these rules were later incorporated into law or securities rules. ${ }^{4)}$

Anyone who studies Korea's securities markets must be impressed by the steady improvements over time and the significant improvements since the 1997 financial crisis. ${ }^{5)}$ And yet, work remains to be done, especially in the broad areas of strengthening the role of the board of directors and constraining the opportunity for self-dealing by the controlling shareholders and senior managers of public companies,

4) See Brian R. Cheffins. Does Law Matter? The Separation of Ownership and Control in the United Kingdom, 30 JouRnal OF Legal Studies 459-484 (2001); John C. Coffee, Jr., The Rise of Dispersed Ownership: The Roles of Law and the State in the Separation of Ownership and Control, 111 YALE LAW JOURNAL 1-82 (2001).

5) For a review of recent changes in Korea's corporate governance rules, see Hwa-Jin Kim, Toward the "Best Practice" Model in a Globalizing Market: Recent Developments in Korean Corporate Governance, in YEARBOOK OF LAW AND LEGAL PRACTICE IN EAST ASIA (2002), available at <http://ssrn.com/abstract=282051> (Social Science Research Network). 
perhaps especially within chaebol groups.

This paper is not the place to detail the areas where Korea's rules in these areas could be improved. I did so at length in a World Bank sponsored report to the Korean Ministry of Justice on potential reforms to the Commercial Code. I will refer to this report as the World Bank Report. $\left.{ }^{6}\right)$ This report met strong opposition from chaebol managers. In their view, reform has gone too far already, and further reforms can be left to market forces. Their hope is that market forces will in fact not force them to reform much more than they already have, or at least will not do so too quickly.

The reality is that Korea has world class companies, but does not yet have world class corporate governance. As a result, the shares of Korean companies trade at a substantial "Korea discount" to the values they could potentially achieve, based on the earning power of these companies. For example, a cross-country by Tatiana Nenova reports that the discount in value, due to the voting control exercised by the controlling families of Korean firms, is around $30 \%$ of the value of the firm. In contrast, the value of high-voting shares in the United States, for those companies that have two classes of voting shares, is under $5 \%$ of the value of the firm. ${ }^{7)}$ My own research with Professors Hasung Jang and Woochan Kim, documents how the corporate governance practices of Korean companies can powerfully affect the market value of their shares. In our study, which covers essentially all KSE-listed firms, a worst-to-best change in governance practices predicts roughly a doubling in share price. ${ }^{8)}$ The bottom line: It is not yet feasible to imagine a major Korean company buying a major Western company and paying with its own shares.

Perhaps because of political opposition from the chaebol, only a few of the World Bank Report's major recommendations have thus far been implemented. Of these,

6) Bernard Black, Barry Metzger, Timothy J. O'Brien \& Young Moo Shin, Corporate Governance in Korea at the Millennium: Enhancing International Competitiveness (Report to the Korean Ministry of Justice, May 2000), 26 JOURNAL OF CORPORATION LAW 537-609 (2001). available at <http://ssrn.com/abstract=222491> (Social Science Research Network) (Korean version available on request from the authors).

7) Tatiana Nenova, The Value of Corporate Votes and Control Benefits: A Cross-Country Analysis JouRnAL OF FINANCIAL ECONOMICS (forthcoming 2003), available at <http://ssrn.com/abstract=237809> (Social Science Research Network); see also Alexander Dyck \& Luigi Zingales, Private Benefits of Control: An International Comparison (working paper 2001), available at <http://ssrn.com/abstract=296107> (Social Science Research Network).

8) Bernard Black, Hasung Jang \& Woochan Kim, Does Corporate Governance Affect Firms' Market Values: Evidence from Korea (working paper 2003), available at <http://ssrn.com/abstract=311275> (Social Science Research Network). 
perhaps the most important involves cumulative voting for directors, although the new rules apply only prospectively, and only to companies with assets greater than 2 trillion won. ${ }^{9)}$ There is also serious interest in creating a mechanism for securities class actions. Some smaller changes have been made as well, primarily through amendments to the Korea Commercial Code. Yet amendments to the commercial code, or to securities laws and regulations, are not the only way that disclosure reforms and corporate governance reforms can take place. Many reforms can be adopted through changes in stock exchange rules.

\section{The KSE's Limited Role to Date}

Sadly, the Korea Stock Exchange has not been a leader in addressing the disclosure and corporate governance practices of listed firms. The Exchange is interested in improving its level of self-regulation, as attested by its sponsorship of the conference for which this article was prepared. It is interested in understanding the corporate governance practices of member firms, as attested by its sponsorship of an annual corporate governance survey, first conducted in 2001, on which my research with Professors Jang and Kim is based. The KSE was, happily, willing to share the survey results with us. It has recently created the Korea Corporate Governance Service, under the leadership of Professor Kwang Chung of Chung-Ang University, to continue corporate governance research. At the same time, the KSE has thus far defined selfregulation to include primarily policing broker-dealers and policing trading, not policing listed companies.

This, I believe, is a major missed opportunity. Many of the recommendations in the World Bank Report could be adopted for listed companies through KSE rules. Indeed, in at least one instance, this was our expectation. In 1999, a Committee on Improving

9) Korean companies must give shareholders an opportunity to elect directors using cumulative voting unless the company charter provides otherwise. Korean Commercial Code art. 382-2. However, almost all public companies have eliminated cumulative voting in their charters. For companies with at least 2 trillion won in assets, the new rules allow shareholders to approve a charter amendment to eliminate cumulative voting only by a 2/3 majority vote, in which the controlling shareholder group is limited to 3\% of the total votes. Korea Securities Exchange Act art. 191-18(2) (amended 2001). It is widely believed that companies subject to these rules will not be able to persuade their shareholders to opt out of cumulative voting. However, this will not change the situation for companies that have already opted out of cumulative voting, or companies that do so before crossing the 2 trillion won threshold. 
Corporate Governance, organized by the Ministry of Finance and Economy, adopted a non-binding Code of Best Practices for Corporate Governance. (the "Best Practices Code"). We expected that disclosure by each listed firm about the extent to which a firm has complied with the Best Practices Code would be required by KSE listing rules. This is the approach taken in a number of other countries. For example the listing rules of the London Stock Exchange require listed companies to report on their compliances with the British Combined Code on Corporate Governance. Yet the KSE has not yet taken this modest step.

I strongly recommend greater action in this area by the Korea Stock Exchange. I believe that the Exchange should appoint a committee to review the World Bank Report and the Best Practices Code and decide which of the recommendations in these sources should be incorporated into KSE listing rules.

\section{The Two-Tier Market Strategy}

The Korea Stock Exchange is subject to the same political pressures that, in some cases, have limited Korean legal reforms. Some of the major members of the Exchange are affiliated with chaebol groups. Even those who are not want to stay on good terms with the chaebol, to enhance their chances of doing business with chaebol group members. Let me therefore suggest a strategy, pioneered in Germany with the Neuer Markt and then copied in Brazil with the Novo Mercado, that has the potential to raise corporate governance standards without provoking strong opposition from major companies.

This approach involves a two-tier market, where new companies can go public through a new market (perhaps a separate tier of the KSE) that has tougher corporate governance standards than the existing market. Other listed companies may, but are not required to, comply with these higher listing standards and qualify for this upper tier. The core of this strategy is the belief that strong corporate governance standards will attract investors. ${ }^{10)}$ Some companies will comply, to raise their share prices or facilitate issuing shares. Others will prefer not to comply, to preserve greater room for self-dealing and other private benefits of control that might be limited by the tougher rules. Companies

10) See Craig Karmin \& Jonathan Karp, Brazilian Market Tries Friendly Approach: Novo Mercado's Rules Aim to Help Minority Holders, NEW YoRK TIMES, May 10, 2001, at page C1. 
which would fight these reforms if they were applied to all listed companies can be left alone.

These dual-market attempts are new. The Neuer Markt appeared to be a success of a while, but eventually failed after the collapse of the Internet bubble, and was merged into the Frankfurt Stock Exchange. It remains in existence as a branch of the Frankfurt Stock Exchange, but whether it will attract significant new listings remains uncertain.

Still, the KSE has perhaps a unique opportunity to create an upper-tier market that will include, from day 1, all major companies, and thus should attract the trading volume it needs to be viable. The KSE could begin by adopting listing standards, including a minimum of $50 \%$ outside directors, an audit committee, and board approval of related-party transactions, that incorporate rules that are already mandatory for large companies (with assets over 2 trillion won) and banks. This would instantly make the upper tier the principal trading market, and create significant pressure on smaller companies to adopt these rules voluntarily. By doing so, these smaller firms could obtain, at low cost, a public signal of their compliance with these governance practices. Conversely, if they failed to join the upper tier, they would signal their disregard for shareholder interests, and likely pay a penalty in their share price.

Once the upper-tier is established, it should be feasible for the KSE to gradually raise the standards for membership. Political opposition by member firms will still exist, but can be muted by the counterargument that membership in the upper tier is, after all, voluntary.

In the end, an upper tier with higher governance standards is likely to be a secondbest substitute for stronger rules to govern all listed companies. Still, it offers a strategy that the Korea Stock Exchange or the KOSDAQ may find appealing. ${ }^{11)}$

\section{The Battle for Trading in Cross-Listed Companies}

Let me add urgency to the importance of stronger self-regulation, across all dimensions but especially for disclosure and corporate governance rules for listed companies, by observing that the Korean Stock Exchange is highly likely to face

11) For a similar proposal, see Stephen J. Choi \& Kon Sik Kim, Establishing a New Stock Market for Shareholder Value Oriented Firms in Korea, CHICAGo Journal of INTERNATIONAL LAW (forthcoming 2003) available at <http://ssrn.com/abstract=314921> (Social Science Research Network). 
increasing competition for trading volume from other exchanges. The practice by large companies of cross-listing their shares on major world exchanges is still the exception in Korea, and not the rule. ${ }^{12)}$ This is likely to change.

There is substantial evidence that share prices increase when companies cross list their shares on a world-class stock exchange. The most likely reason for this price increase is that by cross-listing, companies bind themselves to follow foreign corporate governance practices. This is why the price increase for foreign companies that cross list in the United States is weakest for companies that adopt level $1 A D R s$, which do not require compliance with U.S. disclosure rules, stronger for companies that adopt level $2 A D R s$, which require partial compliance with U.S. rules, and strongest for level $3 A D R s$, which require full compliance with U.S. securities rules. ${ }^{13)}$

Moreover, the weaker Korea's corporate governance and trading rules, the stronger the incentives for listed companies to cross-list elsewhere, to bond their promise to behave well. The better governed a firm is, the stronger its incentive to demonstrate its commitment to good governance by cross-listing. Eventually, just as -- if the KSE adopts the two-tier market approach suggested above -- failure to qualify for the upper tier of this market will signal that the firm's insiders give little weight to minority shareholder interests, so to, for Korea's largest firms, failure to cross-list will become a signal that the firm does not want to be subject to world-class corporate governance standards. Investors will price the firm's shares accordingly.

Trading, too, will migrate. Individual Korean investors cannot easily trade shares on the New York Stock Exchange or NASDAQ. But the difficulty of doing so will decline over time. For institutional investors, the locus of the market doesn't make much difference. But neither does it take much to persuade institutional investors to prefer one market over another. Moreover, trading tends to concentrate in a single market, because investors want to trade where other investors also trade.

Thus, cross-listing can lead to a tipping of the balance between the local exchange and the foreign exchange, where the foreign exchange begins to attract most of the trading in cross-listed firms. This tipping is already common for Latin American

12) As of late 2001, 5 companies listed on the Korea Stock Exchange have cross-listed on the New York Stock Exchange, two companies listed on KOSDAQ have cross-listed on NASDAQ, and one Korean company has gone public with a primary listing on NASDAQ. The cross-listings involve level 2 ADRs. Even smaller numbers of Korean companies have cross-listed on other world exchanges. See Hwa-Jin Kim, Searching for a Model for Effective SelfRegulation in Korea, in Hwa-Jin Kim, ed., SELF-REgUlation in the Korean SeCURITIES MARKET 7-15, at 15 (2003). 
companies. Once this happens, the transfer of trading is self-reinforcing and very hard to reverse. ${ }^{14)}$ If these firms account for most of the volume in their home exchange, the local exchange can hollow out and lose the critical mass needed to sustain either strong self-regulation or adapt to technological advances.

If Korean regulators and the Korea Stock Exchange want to prevent this tipping from occurring for Korean companies, they must act before the tipping happens. Once tipping occurs, it is likely to be irreversible. Strengthening its corporate governance and other investor protection rules are an important part of how the Korea Stock Exchange can keep trading onshore.

Here, though, self-regulation is not enough. Korea's $0.5 \%$ securities transaction tax sends a clear message to institutional investors, who can trade ADRs without paying this tax, that they should trade ADRs of Korean companies in New York, instead of trading shares in Korea, as soon as cross-listing permits investors to do so.

Institutional investors are acutely sensitive to trading costs. They will switch brokers to reduce commission costs by $\$ .01 /$ share, which is 1 part in 5000 if they are trading shares worth $\$ 50$ each. The securities transaction tax in Korea is 1 part in 200 -- equivalent to an additional commission of $\$ 0.25$ on shares worth $\$ 50$ each. This is not sustainable. It guarantees that when Korean companies cross-list, trading by large investors will follow them to the new exchange, to escape the securities transaction tax. It also provides a further motive for cross-listing. Cheaper trading means higher liquidity, which can translate into higher share prices. ${ }^{15)}$ I hope that the Korean government realizes that this tax is not sustainable before, rather than after, tipping of the dominant locus of trading occurs.

13) See John C. Coffee, Jr., Racing Toward the Top? The Impact of Cross-Listings and Stock Market Competition on International Corporate Governance (working paper 2002), available at $\langle\mathrm{http} / / / \mathrm{ssrn}$.com/abstract=315840> (Social Science Research Network); Craig Doidge, G. Andrew Karolyi \& Rene M. Stulz, Why Are Foreign Firms Listed in the U.S. Worth More (working paper 2002), available at <http://ssrn.com/abstract=285337> (Social Science Research Network); Darius Miller, The Market Reaction to International Cross-Listings: Evidence from Depository Receipts, 51 JouRnAL OF FinANCIAL ECONOMICS 103-123 (1999).

14) For data on migration of trading, see Stijn Claessens, Daniela Klingebiel \& Sergio L. Schmukler, Explaining the Migration of Stocks from Exchanges in Emerging Economies to International Centers (working paper 2002), available at <http://ssrn.com/abstract=296690> (Social Science Research Network); John C. Coffee, Jr., Competition Among Securities Markets: A Path Dependent Perspective (working paper 2002), available at <http://ssrn. com/abstract-283822> (Social Science Research Network).

15) For evidence on the relationship between trading volume(a measure of liquidity) and share prices for Korean firms, see Black, Jang \& Kim (2003), supra note 8. 
Even if Korean trading in cross-listed companies is not crippled by a securities transaction tax, the outcome of the battle for trading in the shares of cross-listed companies is unclear. The time difference between Korea and the United States or London makes it harder for Korean investors to trade in these other exchanges. But this time difference also makes it more convenient for institutional investors in America and Europe to trade in the United States or London. Moreover, if time zone differences are important, the Hong Kong or Singapore stock exchanges can strengthen their markets to attract trading of shares in Korean and other Asian companies.

In a recent assessment of the likely future course of this competition between stock exchanges, John Coffee writes about the risk faced by country exchanges:

[R]egional "super-markets" might develop from exchanges that already had relatively high disclosure standards and could offer greater credibility to companies incorporated in jurisdictions perceived by investors as having weak corporate governance standards. Conversely, firms less interested in attracting minority investors (but still desiring some degree of liquidity) might trade only on lower-disclosure exchanges (such as the Korean or Shanghai Stock Exchanges). ... While single country exchanges will endure in large market countries (e.g., Korea in Asia or Milan in Italy), they seem likely to progressively lose trading volume to the regional "super-market"). ${ }^{16}$

Korean corporate governance has greatly improved since the 1997 financial crisis. Yet, it is fair to say that Korean practices do not yet meet the standards of Singapore and Hong Kong. For example, in a recent survey of corporate governance in 10 Asian countries by Credit Lyonnais Securities Asia, Korea tied with Malaysia for 5th, with an average score of 5.5 on a $0 \sim 10$ scale, compared to 7.7 for Singapore and 7.3 for Hong Kong. ${ }^{17)}$ Another recent multicountry study reports that enforcement, especially private

16) Coffee(2002), supra note 14.

17) Credit Lyonnais Securities Asia, Corporate Governance In Asia: Fakin It (April 2003).

18) See Rafael La Porta, Florencio Lopez-de-Silanes and Andrei Shleifer, What Works in Securities Laws? (working paper 2002) 
enforcement, is a key factor in determining the size of securities markets. ${ }^{18)}$ Yet, in the Credit Lyonnais survey, Korea scores especially poorly on a measure of enforcement, at 3.5 versus 7.5 for Singapore and 6.5 for Hong Kong.

Thus, I believe that Professor Coffee's prediction will come true, unless the Korean Stock Exchange and Korean securities regulators aggressively upgrade Korea's disclosure and corporate governance standards. The time left for the KSE and the KOSDAQ to fight this battle and survive as important stock markets is limited. My guess is that the time period is no more than 10 years. The battle is unwinnable without repeal of the securities transaction tax. But even with repeal of this tax, the battle will be lost if it is not fought. The Korea Stock Exchange, I think it is fair to say, is not yet fighting.

This evaluation may seem harsh. But a decade ago, no one thought that the dominant locus of trading in major Latin American companies would migrate to the New York Stock Exchange. Today, this migration has already happened. The war for trading volume in major Latin America companies is over, before the major Latin American exchanges knew it was taking place.

Governance standards do not change overnight. Investors perceptions of governance standards change even more slowly than the standards themselves. Investor perception of the quality of Korean markets is mixed. If the battle for trading in shares of major companies were fought today, the KSE and the KOSDAQ would lose. To win investor confidence, in competition with Singapore, Hong Kong, London, and New York, Korea must continue, with the same urgency it had after the 1997 financial crisis, to upgrade its disclosure rules and governance rules. Self-regulation through listing standards can form a large part of that effort.

\section{The Organizational Structure of Stock Exchanges}

The current organizational structure of the Korea Stock Exchange, as a non-profit entity owned by broker-dealers, may not be suited for a future of intense competition among stock markets for company listings and for trading volume, with a likelihood of consolidation, through mergers or alliances between exchanges. For-profit exchanges may be able to compete more effectively than nonprofit, broker-controlled exchanges. Most obviously, there is a tension between running a market that is good for investors and running a market that is good for brokers. When that tension arises, a broker- 
controlled exchange will tend to favor brokers over investors in the near term. ${ }^{19)} \mathrm{A}$ government regulator (in Korea, the Ministry of Finance and Economy) can partly restrain this tendency, but only partly, if U.S. experience is any guide.

In the long-run, a half-hearted fight, where the exchange's competitive efforts are hampered by broker-dealers' efforts to preserve local rents, may cause the Korean exchanges to lose the long-run battle for investor confidence and thus for trading volume. That will not be good for brokers either, but they may be slow to anticipate the migration of trading. Broker-dealers may also want to capture what profits they can, while they can. Broker-dealers' reluctance to change, when change is needed to meet the new competitive forces that are sweeping across increasingly global capital markets, is the principal force that is driving major exchanges to convert to for-profit form. Some have already done so, others are planning to do so. ${ }^{20)}$

The KSE is in the early stages of considering such a conversion. But here too, I sense a lack of urgency. Korea's stock markets have been relatively insulated. Foreign investors have been permitted in, over the last 10 years. They have come in large numbers, and were not scared away by the 1997 financial crisis. But only a handful of companies have as yet migrated out, through cross-listing or direct primary listing in another market. Still, the threat looms close. Cross-listing will come. The ability of new Korean firms to conduct initial public offerings offshore will come, even if only one company has thus far done this.

In my judgment, the KSE and the KOSDAQ need to consider, more seriously than they have done to date, whether they can meet that challenge with their current governance structures. I suspect that they cannot. To be sure, the KSE and the KOSDAQ cannot unilaterally decide to change their governance structure. This will require amending the Securities Transaction Law. However, I also understand that Ministry of Finance and Economy favors some form of demutualization of stock and futures exchanges. Thus, the necessary amendments seem possible to achieve.

At the same time, I also understand that the Ministry of Finance and Economy may

19) For theoretical development of this point, see Peter M. DeMarzo, Michael J. Fishman \& Kathleen M. Hagerty, Contracting and Enforcement with a Self-Regulatory Organization (working paper 2001), available at <http://ssrn.com/abstract=279302> (Social Science Research Network).

20) For an overview of the conversion efforts to date, see Roberta S. Karmel, Turning Seats into Shares: Causes and Implications of Demutualization of Stock and Futures Exchanges, 53 HASTINGS LAW JOURNAL $367-428$ (2002).

21) See WORLD STOCK EXCHANGE FACT BOOK (2002); Kim(2003), supra note. 12, at 14 
favor creating a single monopoly exchange, which would hold the KSE, the KOSDAQ, and the Korea Futures Exchange as subsidiaries. I believe this is a mistake. In any industry, monopolists are rarely agile and fast-moving. In the United States, competition between the New York Stock Exchange and NASDAQ has been an important spur to improvements by both.

This final recommendation for demutualization may seem to take me some distance from the topic of self regulation. I believe, though, that the organizational structure of exchanges and their success at self-regulation are closely linked. In effect, a basic self-regulatory job for any stock exchange is to regulate its own organizational structure -- to choose a structure that will let it compete effectively against other exchanges. That organizational structure will then impact the exchange's incentives and ability to engage in other forms of self-regulation.

Let me offer an example of how organizational structure affects self-regulation. I observed earlier that exchanges, as long as they are controlled by their members, will not do a good job of policing moderate overcharging and other ways that brokers take advantage of customers. This situation changes dramatically if the exchange is owned by investors. The exchange must then address both the needs of broker-dealers and the needs of investors, each of whom must be persuaded to use the exchange instead of its competitors. Stronger self-regulation by exchanges of brokers becomes possible, in part because the exchange is not so directly regulating itself -- its members.

\section{Conclusion}

It is entirely possible that within a decade, the competition to become a world-class exchange will be over. The KSE will have succeeded, or the bulk of trading in Korean firms will have moved elsewhere. Complacency will likely produce competitive failure. Consider the Tokyo stock exchange. It remains far larger than Singapore and Hong Kong combined, in both market capitalization and trading volume. ${ }^{21)}$ Yet it is not seen as a major competitive threat. In share trading, as in so much else, the Japanese have been too complacent and seen their competitive advantage erode. Here as elsewhere in corporate governance, Korea can learn from Japan what not to do. 


\section{References}

Black, Bernard S., The Legal and Institutional Preconditions for Strong Securities Markets, 48 UCLA LAW REVIEW 781-858 (2001)

Black, Bernard, Barry Metzger, Timothy J. O’Brien \& Young Moo Shin, Corporate Governance in Korea at the Millennium: Enhancing International Competitiveness (Report to the Korean Ministry of Justice, May 2000), 26 JOURNAL OF CORPORATION LAW 537-609 (2001) available at http://ssrn.com/ abstract=222491 (Social Science Research Network)

Bernard Black, Hasung Jang \& Woochan Kim, Does Corporate Governance Affect Firms' Market Values: Evidence from Korea (working paper 2003), available at http://ssrn.com/abstract=311275 (Social Science Research Network)

CHEFFins, Brian R. COMPANy LAW: THEORY, STRUCTURE, AND OPERATION (1997)

Cheffins. Brian R., Does Law Matter? The Separation of Ownership and Control in the United Kingdom, 30 JOURNAL OF LEGAL STUDIES 459-484 (2001)

Choi, Stephen J., \& Kon Sik Kim, Establishing a New Stock Market for Shareholder Value Oriented Firms in Korea, CHICAGO JOURNAL OF INTERNATIONAL LAW (forthcoming 2003) available at http://ssrn.com/abstract=314921 (Social science Research Network)

Claessens, Stijn, Daniela Klingebiel \& Sergio L. Schmukler, Explaining the Migration of Stocks from Exchanges in Emerging Economies to International Centers (working paper 2002), available at http://ssrn.com/abstract=296690 (Social Science Research Network)

Coffee, John C., Jr., The Rise of Dispersed Ownership: The Roles of Law and the State in the Separation of Ownership and Control, 111 YALE LAW JOURNAL 1-82 (2001)

Coffee, John C., Jr., Racing Toward the Top? The Impact of Cross-Listings and Stock Market Competition on International Corporate Governance (working paper 2002), available at http://ssrn.com/abstract=315840 (Social Science Research Network) 
Coffee, John C., Jr., Competition Among Securities Markets: A Path Dependent Perspective (working paper 2002), available at http://ssrn.com/abstract-283822 (Social Science Research Network)

Credit Lyonnais Securities Asia, Corporate Governance In Asia: Fakin It (April 2003)

DeMarzo, Peter M., Michael J. Fishman, and Kathleen M. Hagerty, Contracting and Enforcement with a Self-Regulatory Organization (working paper 2001), available at http://ssrn.com/abstract=279302 (Social Science Research Network)

Doidge, Craig, G. Andrew Karolyi \& Rene M. Stulz, Why Are Foreign Firms Listed in the U.S. Worth More (working paper 2002), available at http://ssrn.com/ abstract $=285337$ (Social Science Research Network)

Dyck, Alexander, \& Luigi Zingales, Private Benefits of Control: An International Comparison (working paper 2001), available at http://ssrn.com/abstract =296107 (Social Science Research Network)

Karmel, Roberta S., Turning Seats into Shares: Causes and Implications of Demutualization of Stock and Futures Exchanges, 53 HASTINGS LAW JOURNAL 367-428 (2002)

Kim, Hwa-Jin ,Toward the "Best Practice” Model in a Globalizing Market: Recent Developments in Korean Corporate Governance, in YEARBOOK OF LAW AND LEGAL PRACTICE IN EAST ASIA (2002), available at http://ssrn.com/abstract =282051 (Social Science Research Network)

Kim, Hwa-Jin, Searching for a Model for Effective Self-Regulation in Korea, in HwaJin Kim, ed., SElf-Regulation IN THE KOREAN SECURITIES MARKET 7-15 (2003)

Rafael La Porta, Florencio Lopez-de-Silanes and Andrei Shleifer, What Works in Securities Laws? (working paper 2002)

Mahoney, Paul G., The Exchange as Regulator, 83 VIRGINIA LAW REVIEW 1453-1500 (1997)

Miller, Darius, The Market Reaction to International Cross-Listings: Evidence from Depository Receipts, 51 JOURNAL OF FINANCIAL ECONOMICS 103-123 (1999) 
Nenova, Tatiana, The Value of Corporate Votes and Control Benefits: A Cross-Country Analysis JOURNAL OF FINANCIAL ECONOMICS (forthcoming 2003), available at http://ssrn.com/abstract=237809 (Social Science Research Network)

Pritchard, Adam C., Self-Regulation and Trust in the Securities Markets, in Hwa-Jin Kim, ed., Self-Regulation in the Korean Securities Market 31-53 (2003)

Pritchard, Adam C., Self-Regulation and Securities Markets, REGUlation, Spring 2003, at 32-39

WORLD STOCK EXCHANGE FACT BOOK (2002) 